\title{
Unbearable trauma and irreparable damage: maternal death by suicide raises seri-ous perplexities
}

\author{
Kayo Resende Dias e Almeida ${ }^{1}$ iD, Séphora Natércia Albuquerque Oliveira² iD, \\ Modesto Leite Rolim Neto ${ }^{3}$ (D), \\ ${ }^{1}$ Department of Health Science, State University of Santa Cruz, UESC, Ilhéus, Bahia, Brazil. \\ ${ }^{2}$ School of Medicine of Juazeiro do Norte, FMJ/Estácio, Juazeiro do Norte, Ceará, Brazil. \\ ${ }^{3}$ School of Medicine, Federal University of Cariri, UFCA, Barbalha, Ceará, Brazil
}

\section{$\triangle$}

Modesto Leite Rolim Neto

School of Medicine

Universidade Federal do Cariri -

UFCA, Barbalha, Brazil.

Phone: (+55 88) 999042979

Email: modesto.neto@ufca.edu.br

Edited by

Juliana Ramos Andrade

Keywords:

Maternal death

Suicide

Mental disorders

Pregnancy

Postpartum period

\begin{abstract}
Introduction: Maternal death by suicide raises serious perplexities. The ICD-10 classifies maternal suicide as an indirect form of maternal death. Due to this current mis-classification, a classificatory consensus of maternal suicide as a direct form of maternal death is urgent.

Objective: Analyze the psychological that permeate the phenomenon of maternal suicide, to define the profile of mothers in the postpartum period and pregnant women who commit suicide, with the purpose of elucidating ways of preventing maternal sui-cide.

Method: A systematic review was made following the PRISMA protocol (Preferred Reporting ltems for Systematic Reviews and Meta-Analysis).

Results: Twenty-one studies reported the urgent need to implement interventions in order to prevent or reduce mental health problems caused by mothers and pregnant wom-en who commit suicide. Twenty studies demonstrate the need for interventions to organi-zational adjustments, especially related to the emotional conflicts involved suicide and maternity.

Conclusion: Maternal suicide is mainly caused by severe psychiatric disorders, however, higher suicide rates are seen due to psychosocial factors, such as poor familial support and domestic violence, illegal substance abuse and alcoholism, history of sexual or physical violence, racial oppression, economic instability, unwanted pregnancy, diffi-culty in accessing intentional abortion, and trauma related to past maternity experiences.
\end{abstract}




\section{Introduction}

The death of a mother, in of itself, leaves unbearable

trauma and irreparable damage not only for the children but for the entire family and social context surrounding the mother. Hence, the struggle for the survival of pregnant women and mothers in the postpartum period has raised great scientific and social efforts, resulting in the global decline of annu-al rates of maternal death by $46 \%$ between the years of 1990 and $2010 .^{1}$ Most causes of maternal death, such as hemorrhage, eclampsia, malnutrition, infection, and venous thromboembolism, have been combated and mitigated. ${ }^{2,3}$ However, little focus has been placed on maternal suicide, which is now characterized as the primary cause of maternal death in developed countries as well as among the leading causes in developing coun-tries. ${ }^{4}$

Maternal death is defined by the tenth edition of the International Classification of Diseases (ICD-10) as the death by any means of a pregnant woman up to one year af-ter the end of her pregnancy, whether directly, i.e. pregnancy-related obstetric causes, childbirth, and puerperium, or indirectly, due to non-obstetric or pre-existing conditions, aggravated by the effects of pregnancy. ${ }^{5}$ In this context, maternal death by suicide raises serious perplexities. The ICD-10 classifies maternal suicide as an indirect form of maternal death, making these cases even more difficult to classify, analyze, and prevent. ${ }^{6}$ Due to this current misclassification, a classificatory consensus of maternal suicide as a direct form of maternal death is urgent. ${ }^{7}$ Because of this, the discussion for the eleventh edition of the International Classification of Diseases (ICD-11) has proposed to include suicide as a direct form of maternal death in order to facilitate its epidemiological analysis, screening and prevention. 4,6,7 Nevertheless, even with ICD-10 applied the notification and computation of maternal suicides are extremely impaired because there is still no defini-tive, standard classification; many countries, especially the least developed, still do not classify maternal suicides as direct maternal deaths, leading to an important gap in the knowledge of maternal deaths due to suicide worldwide. ${ }^{4}$

In the midst of this situation, maternal suicide continues to reach terrifying rates. There are 2 suicides per 100,000 live births in the USA ${ }^{8}$ and Canada' ${ }^{9}$, while there are 3.7 suicides for every 100,000 in Sweden ${ }^{10}$, and 2.3 per 100,000 in Italy"1, with similar rates worldwide. This paper aims to understand the phenomenon of maternal suicide by quali-tatively analyzing the relationship between suicide and maternity, characterizing causes, issues, and cofactors involved in the process of maternal suicide, as well as proposing pre-ventative measures. Above all, this paper aims to identify who are the mothers and preg-nant women who commit suicide.

\section{Method}

A systematic revision was made, following the PRISMA protocol (Preferred Re-porting Items for Systematic Reviews and Meta-Analysis).

\section{Inclusion criteria}

To search for studies, the following databases were used: Pubmed Scopus and Embase. We identified categorized references for the "Maternal death"; "Suicide"; "Mental disor-ders"; "Pregnancy"; "Postpartum period". Besides, we identified references by searching (title/abstract) in the database, using the keywords: suicide ${ }^{*}$, psych ${ }^{*}$, stress ${ }^{*}$, ans ${ }^{*}$, depr $*$, mental $*$. We selected all references identified specifically for the inclusion criteria for this systematic review.

\section{Data extraction and methodological quality assessment}

We have developed a data extraction form to collect data on participants and exposure intervention, if relevant, results related to relationship between suicide and maternity, characterizing causes, issues, and cofactors involved in the process of maternal suicide. We extracted data on mental health problems, as well as related ones (that is, risk/resilience factors); strategies implemented or accessed by with the objective to identi-fy who are the mothers and pregnant women who commit suicide.

Three researcher (MLRN, SNAO and NNRL) extracted data and another verified the extraction. Three researchers (KRDA, FC and MMMB) independently assessed the methodological quality of systematic reviews using the AMSTAR tool' ${ }^{12}$ and qualitative studies using the CASP checklist (Critical Appraisal Skills Program - CASP). ${ }^{13}$ A re-searcher (MLRN) assessed the quality of cross-sectional studies using the JBI Prevalence or the JBI Cross-sectional analytical checklist and longitudinal studies using the JBI Co-hort checklist (Johanna Briggs Institute) . ${ }^{14}$

\section{Data presentation and analysis}

We summarized the results narratively. We described interventions and outcomes based on the 
information provided in the studies. We decided not to perform a quantitative analysis of summaries of the associations between the various correlates and health fac-tors, due to a combination of heterogeneity in the measures and lack of control groups, and an embraced lack of descriptions necessary to confirm sufficient homogeneity. We rated the certainty of the evidence using the GRADE approach - (Grading of Recom-mendations Assessment, Development and Evaluations. ${ }^{15}$

\section{Results}

The search strategy yielded 229 results in Pubmed Scopus and Embase. Titles and/or abstracts of these records were screened and 156 did not meet the eligibility criteria. Out of the remaining 73 full-text articles, 32 were excluded for various reasons, such as lack of relevancy to the proposed topic. Thus, our systematic review includes 41 publications (Figure 1 and Table 1).

\section{Figure 1. PRIMA flow diagram.}

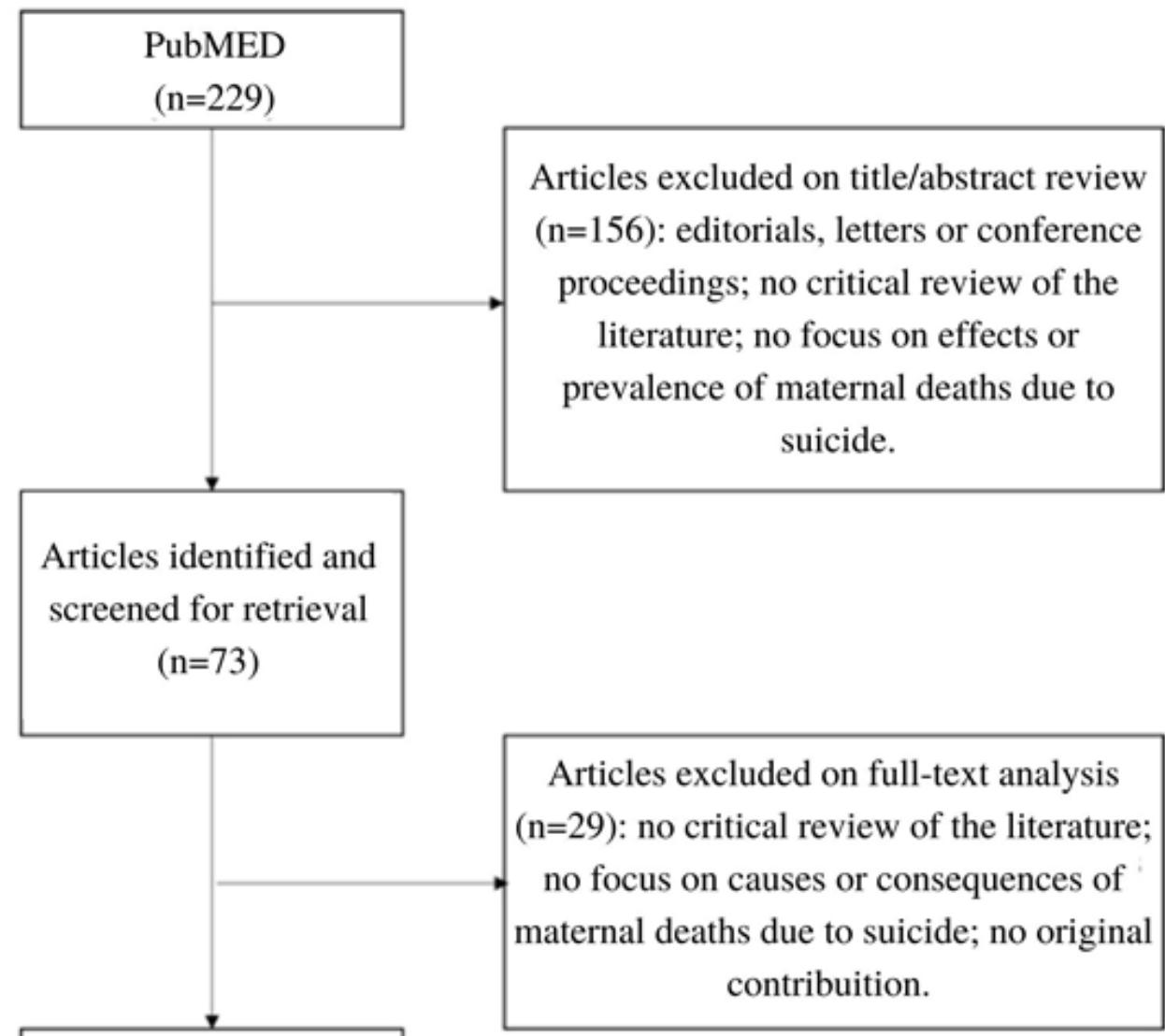

Articles retrieved for more detailed evaluation $(n=44)$

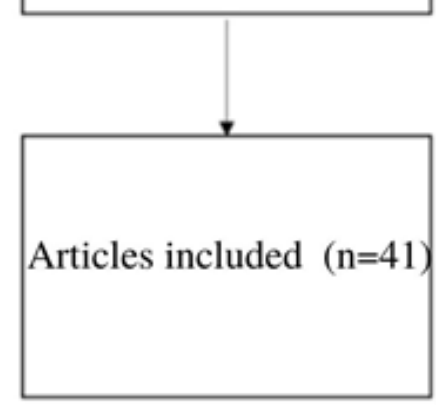


Tabela 1. Porcentagem de resistência aos antibióticos de uso oral de acordo com o total de amostras de cada microrganismo isolado.

\begin{tabular}{|c|c|c|c|c|c|}
\hline Article Title & Author & Year & $\begin{array}{l}\text { Name of Journal } \\
\text { or Magazine }\end{array}$ & Methods used in the study & Significant outcomes \\
\hline $\begin{array}{l}\text { Maternal Deaths From Suicide } \\
\text { nnd Overdose in Colorado, } \\
2004-2012\end{array}$ & $\begin{array}{l}\text { Metz, Royner, } \\
\text { Holfman, } \\
\text { Alstouse, } \\
\text { Beckwith, } \\
\text { Binswanger }\end{array}$ & 2016 & $\begin{array}{l}\text { Obstetrics and } \\
\text { gynecology }\end{array}$ & $\begin{array}{l}\text { Case series of all women with } \\
\text { pregnancy-associated deaths } \\
\text { rom self-harm in Colorado } \\
\text { between } 2004 \text { and } 2012 \text {. } \\
\text { Data was extracted from } \\
\text { state death certificates data } \\
\text { and other sources such as } \\
\text { prenatgl care and delivery } \\
\text { hospitalization records. }\end{array}$ & 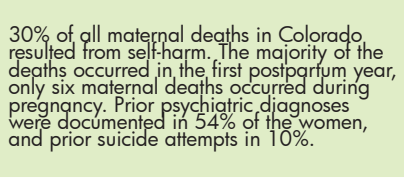 \\
\hline $\begin{array}{l}\text { The prevalence and correlates } \\
\text { of depressive symptoms } \\
\text { among adolescent mothers: } \\
\text { results from a } 17 \text {-year } \\
\text { longitudinal study }\end{array}$ & $\begin{array}{l}\text { Gayin, } \\
\text { Lindhorst, Lohr }\end{array}$ & 2011 & Women \& health & $\begin{array}{l}\text { longitudinal study. Multiple } \\
\text { ogistic regression was used } \\
\text { to estimate the associations } \\
\text { between gorrelates and } \\
\text { elevated depressive } \\
\text { symptoms during five distinct } \\
\text { developmental periods of the } \\
\text { life course. }\end{array}$ & 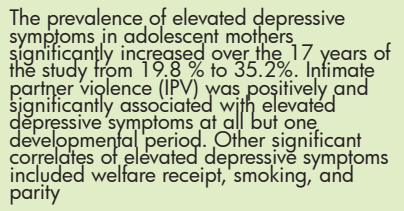 \\
\hline 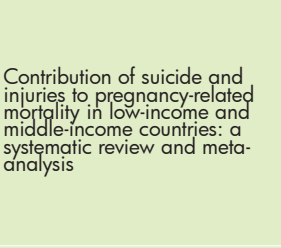 & $\begin{array}{l}\text { Fuhr, Calvert, } \\
\text { Ronsmans, } \\
\text { Chandra, } \\
\text { Sikander, Silva, } \\
\text { Patel }\end{array}$ & 2014 & $\begin{array}{l}\text { The Lancet. } \\
\text { Psychiatry }\end{array}$ & 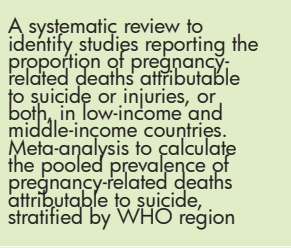 & 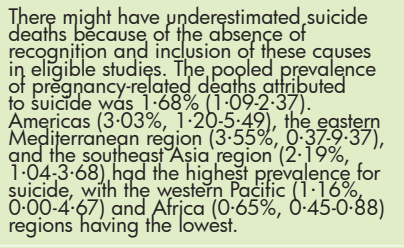 \\
\hline $\begin{array}{l}\text { Homicide and suicide dyring } \\
\text { the perinatal period: findings } \\
\text { trom the National Violent } \\
\text { Death Reporting System. }\end{array}$ & $\begin{array}{l}\text { Palladino, } \\
\text { Singh, } \\
\text { Campbell } \\
\text { Flynn, Gold }\end{array}$ & 2011 & $\begin{array}{l}\text { Obstetrics and } \\
\text { gynecology }\end{array}$ & $\begin{array}{l}\text { An observational time-series } \\
\text { study usiing data of female } \\
\text { yitcims of reprodyctiva age } \\
\text { from the Nationa Violent } \\
\text { Death Reporting System. }\end{array}$ & $\begin{array}{l}\text { There were } 94 \text { counts of pregnancy- } \\
\text { associated suicide, yielding gregnancy- } \\
\text { associated suicider rate of } 2.0 \text { deaths per } \\
100,000 \text { ive births Native Ameritans } \\
\text { showed more suicide rates than oher racial } \\
\text { groups. } 54.3 \% \text { of pregnancy-associated } \\
\text { suicides involved intimate partner contlict }\end{array}$ \\
\hline $\begin{array}{l}\text { Mental Health and Maternal } \\
\text { Mortaliti-When New Life } \\
\text { Doesn'ty Bring Joy. }\end{array}$ & $\begin{array}{l}\text { Jago, Crawford, } \\
\text { Gill, Gagnon }\end{array}$ & 2020 & $\begin{array}{l}\text { Journal } \\
\text { dobstetrique et } \\
\text { gynecologie du } \\
\text { Canada }\end{array}$ & $\begin{array}{l}\text { Retrospective cohort study } \\
\text { using data from the Allberta } \\
\text { Perinatal Health Program from } \\
1998 \text { to } 2015 \text {. }\end{array}$ & $\begin{array}{l}\text { The pregnancy-related maternal mortality } \\
\text { rate tor suicide up to } 3655 \text { days glter birth } \\
\text { was } 2.05 \text { deaths per } 100 \text {, ood deliveries. } \\
\text { Close to } 1 \text { in } 5 \text { maternal deaths in the study } \\
\text { were related to suicide or drug toxicity }\end{array}$ \\
\hline $\begin{array}{l}\text { Suicides during pregnancy } \\
\text { and l year osstartum in } \\
\text { Sweden, 1980-2007 }\end{array}$ & $\begin{array}{l}\text { Esscher. } \\
\text { Essén, Innala, } \\
\text { Papadopoulos, } \\
\text { Skallidoo, } \\
\text { Sundström- } \\
\text { Poromag, } \\
\text { Högberg }\end{array}$ & 2016 & $\begin{array}{l}\text { The British journal } \\
\text { of psychiatry }\end{array}$ & $\begin{array}{l}\text { An observational time-series } \\
\text { study using data of the } \\
\text { Sweddsh Cause of Death } \\
\text { Register, Medical Dirth } \\
\text { Register, and National Patient } \\
\text { Register, besides obstetric } \\
\text { medical records. }\end{array}$ & $\begin{array}{l}\text { The maternal suicide ratio was } 3.7 \text { per } 100 \\
\text { 000 live births for the period } 1980-2007 \text {. } \\
\text { The suicide ratio was higher in women born } \\
\text { in lowincome countries. Violent suicide } \\
\text { methods were common. Most of the victims } \\
\text { had psychiatric care at some point. }\end{array}$ \\
\hline Maternal suicide in Italy & $\begin{array}{l}\text { Lega, } \\
\text { Maraschini, } \\
\text { DA Aloja, } \\
\text { Andreózzi, } \\
\text { Spettoli, } \\
\text { Giangréco, } \\
\text { Vichi, Loghi, } \\
\text { Donati, } \\
\text { Regional } \\
\text { maternal } \\
\text { mortality } \\
\text { working group }\end{array}$ & 2020 & $\begin{array}{l}\text { Archives of } \\
\text { wompen's mental } \\
\text { health }\end{array}$ & $\begin{array}{l}\text { An observational time-series } \\
\text { study using data of the } \\
\text { egiongl degth registries, } \\
\text { hospital discharge databases, } \\
\text { and other data sources. }\end{array}$ & $\begin{array}{l}\text { In Italy the maternal suicide ratio was } 2.30 \\
\text { per } 160,000 \text { live births in } 2006-2012 . \\
\text { The suicide rate was } 1.18 \text { per } 100,000 \\
\text { after giving birth, } 2.77 \text { atter an induced } \\
\text { abortion, and } 290 \text { after a miscarriage. } \\
\text { The maiprity of the women who died by } \\
\text { maternal suicide had a previous psychiatric } \\
\text { history. }\end{array}$ \\
\hline $\begin{array}{l}\text { Suicide risk in relation to } \\
\text { socioeconomic, demographich } \\
\text { psychiatric, and familial } \\
\text { actors: a nationnal register- } \\
\text { based study of all suicides in } \\
\text { Denmark }\end{array}$ & $\begin{array}{l}\text { Qin, Agerbo, } \\
\text { Mortensen }\end{array}$ & 2003 & $\begin{array}{l}\text { The American } \\
\text { iournal of } \\
\text { psychiatry }\end{array}$ & $\begin{array}{l}\text { An observational time-series } \\
\text { study using data of four } \\
\text { national Danish longitudinal } \\
\text { registers. }\end{array}$ & 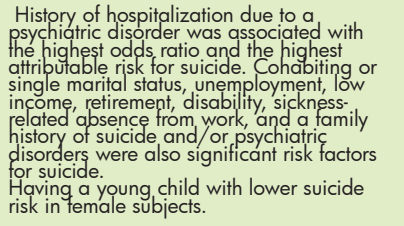 \\
\hline $\begin{array}{l}\text { life cycle and suicidal } \\
\text { behavior among women }\end{array}$ & $\begin{array}{l}\text { Mendez-Bustos, } \\
\text { Lopez-- } \\
\text { Castroman, } \\
\text { Baca-García, } \\
\text { Ceverino }\end{array}$ & 2013 & $\begin{array}{l}\text { The Scientific } \\
\text { World Journal }\end{array}$ & $\begin{array}{l}\text { Literature review. Narrative } \\
\text { description of the evolution of } \\
\text { female suicidal rates during } \\
\text { a lifetime. }\end{array}$ & 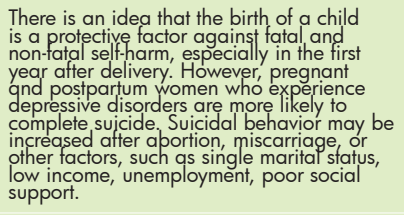 \\
\hline $\begin{array}{l}\text { Bipolar disorder, affective } \\
\text { psychosis, and schhizophrenia } \\
\text { in pregnancy and the } \\
\text { postpartum period }\end{array}$ & $\begin{array}{l}\text { Jones, Chandra, } \\
\text { Dazzan } \\
\text { Howard }\end{array}$ & 2014 & Lancet & $\begin{array}{l}\text { literature review. The evidence } \\
\text { summarized regarding } \\
\text { epidemiology, risk tactors, } \\
\text { and treatment of severe fental } \\
\text { illness in relation to childbirth. }\end{array}$ & $\begin{array}{l}\text { Suicide is a leading cquse of maternal } \\
\text { death Severee mentalillnesses are strongly } \\
\text { associated with suicide in pregnancy } \\
\text { and in the postpartum period, such as } \\
\text { bipolar disorder, affective psychosis, major } \\
\text { depression, and schizophrenia. }\end{array}$ \\
\hline $\begin{array}{l}\text { Maternal mortality and } \\
\text { psychiattric morbidily in the } \\
\text { perinatal preriod: challenges } \\
\text { and oppoortunitives for } \\
\text { prevention in the Australian } \\
\text { setting }\end{array}$ & $\begin{array}{l}\text { Austin, Kildea, } \\
\text { Sulliván }\end{array}$ & 2007 & $\begin{array}{l}\text { The Medical } \\
\text { iournal of } \\
\text { Australia }\end{array}$ & $\begin{array}{l}\text { Comparative study. Analyses } \\
\text { of three reports on maternal } \\
\text { deaths in Australia. }\end{array}$ & 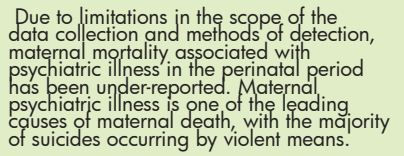 \\
\hline
\end{tabular}




\begin{tabular}{|c|c|c|c|c|c|}
\hline $\begin{array}{l}\text { Suicidality among pregnant } \\
\text { women in Brazil: prevalence } \\
\text { and risk factors }\end{array}$ & $\begin{array}{l}\text { Castro e Couto, } \\
\text { Brancaglion, } \\
\text { Cardoso, } \\
\text { Faria Garcia, } \\
\text { Nicolatar, } \\
\text { Aguiar, Leite, } \\
\text { Corrê, }\end{array}$ & 2016 & $\begin{array}{l}\text { Archives of } \\
\text { women's mental } \\
\text { health }\end{array}$ & $\begin{array}{l}\text { An observational time-series } \\
\text { study using semi-structured } \\
\text { interviews as well as } \\
\text { the Edinburgh Postnatal } \\
\text { Depression Scale Beck } \\
\text { Depression Inventory } \\
\text { and Mini-nternational } \\
\text { Neuropsychiatric Interview } \\
\text { Plus. }\end{array}$ & $\begin{array}{l}\text { The suicide risk among pregnant women } \\
\text { was } 23.53 \% \text {. Antengtal depression, litefime } \\
\text { bipolar disorder, and any current anxiety } \\
\text { disorder were identified as strong risk } \\
\text { factors. Unemployment and fewer years of } \\
\text { education were considered independent } \\
\text { risk factors. }\end{array}$ \\
\hline $\begin{array}{l}\text { Maternal suicide, } \text { Register } \\
\text { based study of gll suicides } \\
\text { occurning dfter delivery in } \\
\text { Sweden 1974-2009 }\end{array}$ & $\begin{array}{l}\text { Lysell, Dahlin, } \\
\text { Viktorin, } \\
\text { Liungberr, } \\
\text { Dennotrio, } \\
\text { Dickman, } \\
\text { Runeson, }\end{array}$ & 2018 & PloS one & $\begin{array}{l}\text { A case-control study designed } \\
\text { with data from Swedish } \\
\text { registries. The cohort consisted } \\
\text { of all women given birth in } \\
\text { Sweden between } 1974 \text { and } \\
\text { 2009. }\end{array}$ & 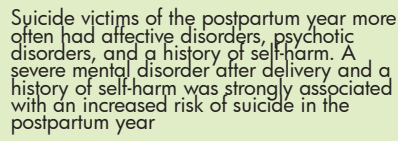 \\
\hline $\begin{array}{l}\text { Perinatal Depression: } \\
\text { Embracing Variability } \\
\text { toward Better Treatment and } \\
\text { Outcomes }\end{array}$ & $\begin{array}{l}\text { Galea \& } \\
\text { Frokjaer }\end{array}$ & 2019 & Neuron & $\begin{array}{l}\text { Literature review. Narrative } \\
\text { description of perinatal } \\
\text { depression. }\end{array}$ & 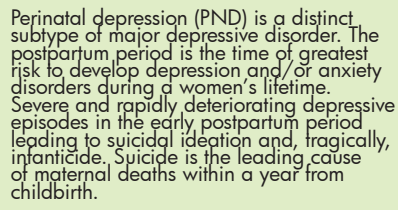 \\
\hline $\begin{array}{l}\text { Suicide during Perinatal } \\
\text { Period: Epidemiology, } \\
\text { Risk Factors, and Clinical } \\
\text { Correlates }\end{array}$ & 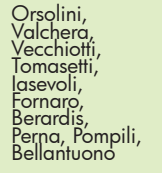 & 2016 & $\begin{array}{l}\text { Frontiers in } \\
\text { psychiatry }\end{array}$ & $\begin{array}{l}\text { A systematic literafure review } \\
\text { in accordance with the } \\
\text { methods recommended by } \\
\text { PRISMA guidelines. }\end{array}$ & $\begin{array}{l}\text { Suicide is one of the leading causes of } \\
\text { maternal mortality. Postpartum depression, } \\
\text { bipolar disorder, postpartum psychosis, and } \\
\text { other mental disordders have been reported } \\
\text { with a higher riks of suicidal ideation, } \\
\text { suicide attempt, or suicide. }\end{array}$ \\
\hline $\begin{array}{l}\text { Epidemiology of Suicide and } \\
\text { the Psychiafric Perspective }\end{array}$ & Bachmann & 2018 & $\begin{array}{l}\text { International } \\
\text { iuurnal of } \\
\text { environmentral } \\
\text { research angl } \\
\text { public health }\end{array}$ & $\begin{array}{l}\text { Wide narrative literature } \\
\text { review. }\end{array}$ & 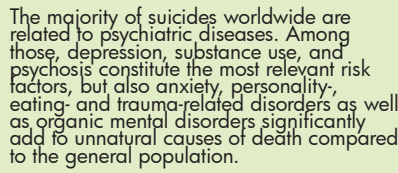 \\
\hline Suicidal mothers & Gentile & 2011 & $\begin{array}{l}\text { Journal of injury \& } \\
\text { violence research, }\end{array}$ & $\begin{array}{l}\text { A narrative review of medical } \\
\text { literature since } 1950, \text { using } \\
\text { Pub Med, Scopus, and Google } \\
\text { Scholar databases. }\end{array}$ & 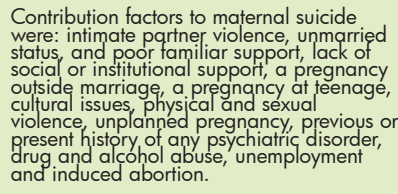 \\
\hline $\begin{array}{l}\text { Suicide and suicide attempts } \\
\text { among women in the } \\
\text { Manitoba Mothers and Fetal } \\
\text { Alcohol Spectrum Disorder } \\
\text { cohort: a retrospective } \\
\text { matched analysis using linked } \\
\text { administrative data }\end{array}$ & $\begin{array}{l}\text { Singal, } \\
\text { Brownell, } \\
\text { Chateau, } \\
\text { Wall-Wijler, } \\
\text { longstaffe, } \\
\text { Hanlon- } \\
\text { Dearman, Roos }\end{array}$ & 2017 & CMAJ Open & $\begin{array}{l}\text { Retrospective cohort anglysis } \\
\text { of women with children born } \\
\text { in Manitobab between } 1984 \\
\text { and } 2012 \text {. }\end{array}$ & $\begin{array}{l}\text { Women with fetal alcohol spectrum } \\
\text { disorder are at increased risk for suicide, } \\
\text { with higher rates of suicidality. }\end{array}$ \\
\hline $\begin{array}{l}\text { Depression and thoughts of } \\
\text { death among disadvantaged } \\
\text { mothers: risk factors and } \\
\text { mpact on maternal and child } \\
\text { health }\end{array}$ & $\begin{array}{l}\text { Crandall, } \\
\text { Sridharan, } \\
\text { Schermer }\end{array}$ & 2010 & $\begin{array}{l}\text { Archiyes of } \\
\text { suicide research }\end{array}$ & $\begin{array}{l}\text { Retrospective database } \\
\text { analysis with bivariate and } \\
\text { multivariate statistics utilizing } \\
3 \text { years of data from the } \\
\text { prospective Fragile Families } \\
\text { and Child Wellbeing Study }\end{array}$ & $\begin{array}{l}\text { Depression and thoughts of death were } \\
\text { significantly associated with ramily violence } \\
\text { and acoholo sse, also increasing the risk of } \\
\text { intant hospitalization Routine screening for } \\
\text { these issues should be implemented. }\end{array}$ \\
\hline $\begin{array}{l}\text { Maternal mortality revisited: } \\
\text { he application of the new } \\
\text { CCDDMM classitication syytem } \\
\text { in reference simaternalem } \\
\text { deaths in Sri Lanka }\end{array}$ & 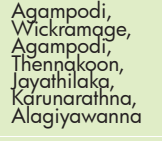 & 2014 & $\begin{array}{l}\text { Reproductive } \\
\text { health }\end{array}$ & $\begin{array}{l}\text { An observational study. Data } \\
\text { analysis of maternal death } \\
\text { surveillance system in North } \\
\text { Central Province of Sri Lanka, } \\
\text { for the period of } 2005 \text { to } \\
2011 \text {. }\end{array}$ & $\begin{array}{l}\text { Classification of maternal suicides as direct } \\
\text { forms of maternal death has an immediate } \\
\text { effect in maising maternal mortality } \\
\text { thresholds, making it easier to understand } \\
\text { the eal number of maternal deaths } \\
\text { attributed to suicide. }\end{array}$ \\
\hline $\begin{array}{l}\text { Prevalence and determinants } \\
\text { of cormmon perinatala mental } \\
\text { disoreders in women in low- } \\
\text { and lower-middle-incom- } \\
\text { countries: a systematic review }\end{array}$ & $\begin{array}{l}\text { Fisher, Cabral } \\
\text { de Méllo, Patel, } \\
\text { Rahman,Tran, } \\
\text { Holton, Holmes }\end{array}$ & 2012 & $\begin{array}{l}\text { Bulletin of the } \\
\text { World Health } \\
\text { Organization }\end{array}$ & $\begin{array}{l}\text { Majior databases were } \\
\text { searched systematically for } \\
\text { English-langygeg publications } \\
\text { on the prevalence of non- } \\
\text { psychofic common perinatal } \\
\text { mental disorders and their risk } \\
\text { factors and determinants. }\end{array}$ & 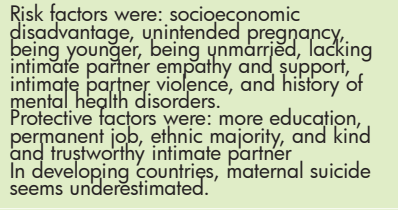 \\
\hline $\begin{array}{l}\text { Maternal deaths from suicide } \\
\text { in Singapore }\end{array}$ & Chen \& Lau & 2008 & $\begin{array}{l}\text { Singapore } \\
\text { medical journal }\end{array}$ & $\begin{array}{l}\text { An observational time-series } \\
\text { study using data from } 2000 \\
\text { to } 2004 \text { in Singapore, by } \\
\text { linking coronial cases of } \\
\text { female suicide in reproductive } \\
\text { gge with the birth registration } \\
\text { database. }\end{array}$ & $\begin{array}{l}\text { Only one maternal degth due to suicide } \\
\text { was identified. Strong tamiliar support in } \\
\text { Singapore max hep to diminish the rates of } \\
\text { maternal suicidality. }\end{array}$ \\
\hline $\begin{array}{l}\text { Antenatal depression and } \\
\text { suicidal ideafion among } \\
\text { rural Bangladeshi women: A } \\
\text { communify-based study }\end{array}$ & $\begin{array}{l}\text { Gausia, Fisher, } \\
\text { Ali, Oosthuizen }\end{array}$ & 2009 & $\begin{array}{l}\text { Archives of } \\
\text { women's mental } \\
\text { health }\end{array}$ & $\begin{array}{l}\text { A community-based study } \\
\text { conducted during } 2005 \\
\text { in the Matlab sub-district, } \\
\text { rural area of eastern } \\
\text { Bangladesh. Interviews were } \\
\text { structured in accordance } \\
\text { with the Edinbugh Postnatal } \\
\text { Depression Scale. }\end{array}$ & $\begin{array}{l}\text { The prevalence of depression and suicide } \\
\text { ideation at } 34-35 \text { weeks pregnancy was } \\
33 \% \text {. Intimate partner violence, unhelptul } \\
\text { and unsupportive familigr context, and } \\
\text { cultural issues were highly associated with } \\
\text { maternal depression. }\end{array}$ \\
\hline $\begin{array}{l}\text { Suicidal ideation during } \\
\text { pregnancy : prevalence and } \\
\text { associated factors among } \\
\text { low-inceme wore wom in Sago } \\
\text { Paulo, Brazil }\end{array}$ & $\begin{array}{l}\text { Huang, Faisal- } \\
\text { Cury, chan, } \\
\text { Tabb, Katon, } \\
\text { Menezes }\end{array}$ & 2012 & $\begin{array}{l}\text { Arch Womens } \\
\text { Mental Health }\end{array}$ & $\begin{array}{l}\text { Cross-sectional gnalysis of } \\
\text { women surveyed during } 20 \text { to } \\
30 \text { weeks of pregnancy using } \\
\text { Self-Report Questionnaire-20. }\end{array}$ & $\begin{array}{l}\text { The prevalence of suicidal ideation was } \\
6.3 \% \% \text { Factors associated with suicidal } \\
\text { ideation were common mental disorders, } \\
\text { single partner status, past psychiotric } \\
\text { history, and smoking fobacco. All cases } \\
\text { of suicidal ideation were associated with } \\
\text { common mental disorders. }\end{array}$ \\
\hline
\end{tabular}



Maternal depression and
suicide at immediate prenata and early postpgrtum periods

Suicidal ideation in Suicidal ideation in
pregnancy: an epidemiologic
review

Intimate partner violence and suicidal ideation in pregnant women

Suicidality in early pregnancy urban India

Antenatal depression in socially high-risk women in

Refugee, asylum seeker, postnatal depression: rates

and risk factors

Maternal depression during pregnancy and the postna period: risks and possible
mechanisms for offspring

depression at age 18 years

Causgs externas e proposta de classificacao

Pregnancy gssociated death in record linkage studies of pregnancy, and natural osses: A systematic review
with a narrative synthesis and meta-analysis

Views and experiences of
suicidal ideation during pregnancy and the postpartum: findings from
interviews with maternal care interviews with
clinic patients

Maternal suicide during pregnancy and the tirst
postpartum year in Austria:
Findings from 2004 to 2017

Perinatal psychiatric disorders: a leading cause of materna
morbidity and mortality

Maternal deaths in NSW 2000-2006) from nonmedical causes (suicide and trauma) in

Maternal suicidality and

suicide risk in oftspring

Maternal or paternal suicide suicide-attempt hospitalization risk

Effects of perinatal mental
disorders on the fetus and
child

Maternal suicidality and risk of suicidality in offspring: study
Shi, Ren, Li, Dai $2018 \quad \begin{aligned} & \text { Psychiatry } \\ & \text { research }\end{aligned}$

Gelayea,

Williams

2016

Archives of

wealth

Alhusen,
Frohman, Purcell

2015

Supraja,

Saryanarayana

Jangam,

2016

Bowem,
Stewart, Baetz,
Muhajartine

2009

community health

$\begin{array}{ll}\text { Archives of } & \text { women between 24-28 weeks } \\ \text { gestation using the Edinburgh }\end{array}$

$\begin{array}{ll}\text { health } & \text { Postnatal Depression Scale } \\ \text { and the Abuse Assessment }\end{array}$

A cross-sectional study of

pregnant women in Southern
India, using. Suicide Behaviors

the Edinburgh Postnatal

Collins,
Zimmerman
Howard

2011

Archives of

health

Pearson, Kounali,

ewis, Heron,

O'Connor, Stein

2013

JAMA psychiatry

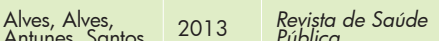

Reardon, Thorp

SAGE open

Tabb, Gavin,

Debiec, Kafon

2013

Women \& health

Knasmüller,

Kapusta, Blüm

Oates

2003 British medical

Thornton,

Dennis, Barnett,

2013

BioMed research

Bronisch, Lieb 2008 $\begin{aligned} & \text { The Psychiatric } \\ & \text { clinics of North } \\ & \text { America }\end{aligned}$

Kuramoto,

Stuart, Runeson,

lichtenstein,

2010 Pediatric

Stein, Pearson,

Goodman,
Rapa, Rahman,
McCallum,

McCallum,
Howard,
Pariante

2014

Lancet

Lieb, Bronisch,
Höfler, Schreie,
Wittchen

2005

The American

journal of
psychiatry

parental disorders and

Comparative study. Baseline
A systematic epidemiologic
review in accordance with

review in accordance
PRISMA guidelines.

Cross-section analysis of

and the

Questionnaire-Revised
and Edinburgh Postnatal
Depression Scale.

A cohort study in two

women groups (Aboriginal

Depression Scale.

nteractive and dynamic
iterature review, conducted across ten databases.

A prospective investigation of associations between
symptoms of antenatal and

symptoms of antenatal and
postnatal parental depression posingtal parental depress
with offspring depression at age 18 years in a UK

An observational time-series
study using data from coronial

registries, hospitalization
registries, besides family

Wide literature review.

An observational study linking

population datasets from and death registratjons
between 2000 and 2007.

Baseline and 4-year follow-up

data were used from the

of Psychopathology Study of Psychopathology Study,
a prospective, longitudiná
community study,

An obseryation study using

population-based registries
between 1973 and 2003 .

There was higher suicidal ideation
ncidence after childbirth. Marital

satisfaction protected women from

depression, while miscarriage experiences increased the risk. Family harmony was a protective tactor, especially harmony with

Pregnant women are more likely than the general population to endorse suicidal education, and major depressive disorder were strongly identified as risk factors.
There is a need for enhanced screening for antepartum suicidal ider

Depressive symptomatology and intimate partner violence were significantly

of antenatal suicidal ideation and, consequently, higher rates of suicidality during pregnancy and the postpartum period.

The severity of depressive symptoms, younger age, economic instability, and history of suicidal ideation were associated
with higher rates of suicidality.

Maternal depression was associated with a history of depression, mood swings, ncreased stressors, current smoker, and
ack of socia support. Aboriginal women were more likely to be depressed and thoughts.

Postnatal depression may affect up to $42 \%$ of migrant women. Common risk factors for postnatal depression include history of
stressfu life events, lack of social support,
and cultural tactors.

Offspring were 1.28 times more likely to have depression at age 18 years for each depression score gntenatally, independent depression score gntenatally, independe depression was also a risk factor for

mothers with low education, with offspring for times more likely to have depression postnatal depression score.

Unplanned pregnancy, illegal intended associated with higher maternal suffering

Termination of pregnancy, miscarriage, with higher mortality rates. Within a year of their pregnancy outcomes, women experiencing a pregnancy loss are over
twice as likely to die compared to women giving birth, with higher risks for suicide.

Suicidality during pregnancy was related to somatic symptoms, past psychiatric history, and pregnancy complications.

All of maternal suicide cases were
performed using violent methods.

All women should be asked early in their pregnancy about a previous history of plans should be in place with regard to the

$67 \%$ of women decegsed due to suicide had a mentgl health diagnosis gnd/or a abuse. $73 \%$ of suicide deaths were

Offspring of mothers reporting suicide attempts showed a remgrkably higher risk for suicida thoughts and suicjde attempts
and a tendency toward suicide attempts at an earlier age.

Maternal suicide is associated with an increased risk of suicide-qttempt associated with maternal accidental death.

Wide literature review,

for associations between

offspring outcomes from fetal development to adolescen
in all income settings.

It is necessary for the eqrly identification mental disorders in order to make earlier jnterventions and prevention researches, especially in socioeconomically countries.

were used from the Early

Developmental Stages of Psychopathology Study, a
prospective, longitudinal
community study.
Sujcidality seems to run in families, psychopathology. 


\section{Evaluation of the methodological quality of the included studies}

The most common methodological weaknesses in all the studies arose from insuf-ficient reporting: samples, scenarios, and recruitment procedures were often not fully de-scribed.

\section{Interventions in mental health}

Twenty-one studies reported the urgent need to implement interventions in order to prevent or reduce mental health problems caused by mothers and pregnant women who commit suicide. Twenty studies demonstrate the need for interventions to organizational adjustments, especially related to the emotional conflicts involved suicide and maternity.

\section{Changes in mental health}

Fifteen of the studies that implemented mental health interventions reported the ef-fects of interventions on emotional conflicts involved suicide and maternity. The only data available to connect the impact of the suicide came from three longitudinal research studies, that report changes over time, both of low-quality methodological value.

The summary of the results table below shows the studies that contribute to each mental health result. We evaluate that the certainty of the reported results of levels of anxiety, depression, distress, and sleep problems in pregnant women who commit suicide, using the GRADE approach, is moderate. 3.9.

\section{Discussion}

Studies report that motherhood can work as a protective factor for mental health, reducing the risk of suicide, especially in pregnant women and women who have recently given birth. ${ }^{16,17}$ However, maternal suicide is a major cause of maternal death around the world, primarily in developed countries. ${ }^{4,18}$ Pregnancy and the arrival of a child represent, for many women, a unique experience of hope and joy, but for some women, this period may become overlapped by serious psychiatric disorders, which destabilize and lead to life-threatening situations for many mothers and pregnant women. ${ }^{18,19}$ In this context, motherhood seems to intensify the prevalence of mental illnesses in vulnerable women ${ }^{3}$, with a history of suicidal thoughts, i.e. a set of suicidal behaviors that include intentional self-harm (with or without the intention to die), suicide ideation and suicide attempts. ${ }^{20}$ Major depressive disorders during pregnancy and the postpartum period, which is consid-ered a main risk factor for maternal suicide, is heavily prevalent, affecting around $20 \%$ of women worldwide, from mild forms to more severe ones and, more rarely, psychosis. ${ }^{4,21}$ Indeed, perinatal depression is a unique subtype of major depressive disorder, where women rapidly experience severe forms of depressive episodes with high levels of comor-bidities such as anxiety, obsessive-compulsive disorders, and ideations of inflicting self-harm and harm to the child. 18,22

Women in mental distress are more likely to commit suicide $^{18}$, mainly in the first months postpartum ${ }^{17,23}$ and during the pregnancy. ${ }^{8,23}$ Studies confirm this notion, stating that the vast majority of pregnant women and mothers who commit suicide are afflicted with severe mental illnesses ${ }^{3}$, such as major depressive disorders and schizophrenia ${ }^{19,24}$, and account for nearly $75 \%$ of all maternal suicides. ${ }^{2,10,24}$ Furthermore, high rates of suicidal behavior are also seen in women with a history of illegal substance abuse ${ }^{23-25}$, alco-holism ${ }^{23,26,27}$, and even tobacco consumption. ${ }^{3} \mathrm{~A}$ study performed in Sri Lanka links the high prevalence of depression in pregnant women, with $27.1 \%$ of the pregnant women having a depressive episode prior to the pregnancy and $16.2 \%$ having postpartum depres-sion, with the high rate of maternal suicides, which represents almost $18 \%$ of all of the causes of maternal deaths in the country. ${ }^{28}$ Suicide is also one of the main causes of ma-ternal deaths in other developing countries, but nonetheless, maternal suicide has re-mained under-investigated and under-diagnosed and consequently under-treated. ${ }^{29}$ The social stigma surrounding taking one's life, as well as inadequate health systems and clas-sificatory obstacles still prevail, which all contribute to the serious problem of underre-porting. ${ }^{4,29}$

In any case, maternal suicide, as with any other psychological phenomenon, does not have one single cause. Pregnant women and mothers in postpartum in such a diverse world could not have the same sufferings nor could they suffer equally in any of their afflictions. However, family support has been shown to be a significant protective factor against maternal suicide ${ }^{29,30}$, while mothers without adequate family support have higher rates of suicide. ${ }^{3,29}$ Guasia et al. ${ }^{31}$ claim that in Bangladesh, unhelpful and unsupportive husbands and mother-in-laws were significant risk factors for suicide, especially for wom-en who have suicidal ideation during pregnancy, which makes up $14 \%$ of all pregnant women in the country. In addition, unmarried or divorced marital statuses, as well as pregnancies outside of marriage are also presented as risk factors for maternal suicide, as these situations could be associated with a lack of familial ties and support. ${ }^{25,32} \mathrm{On}$ the other hand, marital satisfaction was revealed as a protective factor, due to the emotional support provided. ${ }^{33}$ Not surprisingly, teenage mothers may be three times more likely to commit suicide than other age group of women. ${ }^{3,17}$ 
Likewise, domestic violence has been demonstrated to aggravate the risk of ma-ternal suicide. ${ }^{27,34,35}$ In the USA, $54.3 \%$ of women who have committed maternal suicide have experienced some type of domestic abuse..$^{8}$ In India, Supraja et al. ${ }^{36}$ also indicated that domestic violence and inadequate familial and social support had a strong correlation with suicidal ideation in early pregnancy. Furthermore, other types of abuse, whether physical or psychological, are also identified as determining factors for maternal sui-cide ${ }^{20,25}$, such as sexual violence, where studies indicate that mothers who were victims of sexual abuse in the antenatal period have 2 to 4 times more symptoms of depression. ${ }^{3}$

Social contexts of oppression, such as being an ethnic minority, also proves to be of high significance when examining the suicide of mothers and pregnant women world-wide. ${ }^{29}$ In Canada, where approximately 1 in 5 maternal deaths occurs due to suicide or drug toxicity ${ }^{9}$, self-harm ideation rates are alarmingly higher in Aboriginal women, who experience different forms of social disparities, than in other groups of Canadian women. ${ }^{37}$ Similarly, in the USA, Native American women have been reported to have higher rates of maternal suicide than any other ethnic group. ${ }^{8}$ In Sweden, women who have emigrated from developing countries had 3 times more psychiatric morbidities dur-ing postpartum than Swedish immigrants from more developed countries..$^{10}$ This situation-al framework is further intensified in women refugees and asylum seekers, where Collins et al. ${ }^{38}$ report that such groups reach three times higher prevalence of post-natal depression due to serious stressful and traumatic life events in the past.

A range of various social settings has been demonstrated to have significant im-pacts on maternal mental health and, therefore, a direct effect on maternal suicide. Fur-thermore, unemployment and low wages are already well understood to be related to sui-cide in the general population. ${ }^{16,29}$ Supraja et al. ${ }^{36}$ also reported that, in India, the highest prevalence of maternal suicide occurs in middle-class women, potentially due to the un-stable and still growing Indian economy, where even the middle class finds themselves lacking financial stability. There is also evidence that lower levels of education, which may be related to low income and unemployment, is a risk factor for suicide, particularly in the first postpartum year. ${ }^{21,34,39}$

Unplanned or unwanted pregnancies are also des-

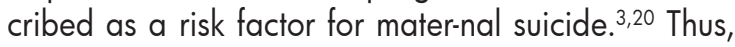
difficult access to abortion services, as well as the illegality of abor-tion in certain countries, also tends to corroborate maternal suffering and possibly sui-cide. ${ }^{25} \mathrm{~A}$ study conducted in Brazil by Alves et al. ${ }^{40}$ associated unwanted pregnancy, the illegality of intentional abortion, and less privileged social condition with maternal sui-cide, where suicide could present itself as the only resource in the face of the despair of women without adequate familial support. Intentional abortion is also associated with higher rates of maternal suicide in some studies. ${ }^{11,17}$ However, the evidence establishes a higher suicide rate after intentional abortion because it stems from traumas experienced during the procedure, and not from the abortion decision or from the act itself. ${ }^{41}$ Miscar-riage and the loss of a child in the first year of life are described as very strong risk factors for suicidal behavior ${ }^{33,42}$, as well as the sorrow of having a stillborn child. ${ }^{21}$

It is important to highlight that the general population of women is less likely to commit violent suicide ${ }^{10}$, however, in the case of maternal suicides, the vast majority of women end up committing suicide violently ${ }^{43}$, mainly by hanging or jumping. ${ }^{44}$ Thornton et al. ${ }^{45}$ refers that, in Australia, $73 \%$ of maternal suicide cases were conducted by violent means, some cases including gunshot and lying in front of a moving object. Maternal dis-tress and suicidal ideation during pregnancy are even associated with gestational and childbirth complications, as well as impairments in the newborn child's physiology, such as reduced dopamine levels and increased cortisol levels. ${ }^{25}$ Revealing the singularity of the phenomenon of maternal suicide, the violent way in which pregnant or in-postpartum women seek to take their own lives opens up the complexity of the theme and the severity of the despair suffered by those who do so. Countless reasons can lead women, both in the pregnancy period and in the postpartum period, to attempt violence against their own lives. Many studies are in consensus that maternal suicide presents itself as a serious and unique psychiatric phenomenon despite the social factors strongly associated with suicidal behavior mentioned above.11,18,20,22 Thus, a history of mental illness such as depression, anxiety, bipolarity, post-traumatic stress disorder, suicide ideation, substance abuse, or any other effect of psychotic disor-der, in addition to a family history of psychiatric diseases and suicide is a primary risk factor for maternal suicide. 16,18,19,25,32

The death of a pregnant or a puerperal woman by suicide is a tragedy of incalcula-ble damage, which carries immeasurable psychological damage for the entirety of their life. ${ }^{46}$ The descendants of mothers who come to commit suicide are at an increased risk of also committing suicide ${ }^{47}$, in addition to being prone to numerous other psycho-emotional disorders. ${ }^{46,48,49}$ Lieb et al. ${ }^{49}$ still indicate that suicidal behavior may have genetic factors involved as well, as though suicide could run in 
families. Therefore, antenatal treatment of depression can prevent higher rates of suicide in the offspring. ${ }^{39}$

\section{Conclusion}

Women who commit maternal suicide are, above all, women with serious mental illnesses $18,19,22$, and with suicide aggravated by serious situations of psychosocial vulnera-bilities, those of which include poor familial support ${ }^{30,33}$, domestic abuse ${ }^{34,35}$, a history of sexual abuse ${ }^{3}$, illegal substance abuse and alcoholism $24,26,27$, specific racial oppression ${ }^{10,37}$, economic instability ${ }^{21,36}$, and unwanted pregnancy combined with difficulty or illegality to perform intentional abortion ${ }^{40}$, in addition to severe trauma related to motherhood, such as miscarriage and loss of child during the delivery or within the first year of life..$^{42}$

Considering that pre-existing mental illness is strongly associated with most sui-cide cases, maternal suicides must be considered preventable with adequate medical care, especially with primary health care. ${ }^{6}$ With the universal and systematic screening of men-tal illness in the earlier stages of pregnancy ${ }^{23,48}$, about a quarter of all maternal suicides could be prevented ${ }^{44}$, with adequate pharmacological therapy and comprehensive psycho-logical assistance. ${ }^{42}$ Regarding the profile of pregnant women and mothers in the postpar-tum period who have committed suicide, it is imperative to develop multidisciplinary monitoring standards for the preventative care for suicide in women defined as most vul-nerable ${ }^{2,48}$ in all levels of care. ${ }^{29}$ Special treatments must be focused mainly on pregnant women who have related a past of psychiatric disorders or addictions ${ }^{23,27}$, or even a histo-ry of suicide in the family ${ }^{16}$, with great attention given to unmarried women, unemployed women, women in the course of unwanted pregnancy, those who have suffered from traumatic experiences, such as physical or sexual violence, those who lack adequate sup-port from family and those belonging to marginalized social groups. ${ }^{24,25,38}$ Furthermore, there is an urgent need for a consensus on the classification of maternal suicide ${ }^{4}$, in order to avoid misclassification bias and enable better analysis of the theme. ${ }^{6,7,19}$

Conflict of interests: The authors declare that they have no competing interests.

Kayo Resende Dias e Almeida

https://orcid.org/0000-0002-4017-422X

Séphora Natércia Albuquerque Oliveira

https://orcid.org/0000-0002-1381-7453

Modesto Leite Rolim Neto

https://orcid.org/0000-0001-9379-2120

\section{Referências}

1. World Health Organization, World Bank, United Nations Popula-tion Fund and United Nations Children's Fund (UNICEF). Trends in maternal mortality: 1990 to 2010: WHO, UNICEF, UNFPA and The World Bank estimates [Internet]. 2012 [cited 2021 16 Sep]. Available from: https://apps.who.int/iris/ handle/10665/44874.

2. Metz TD, Rovner P, Hoffman MC, Allshouse AA, Beckwith KM and Binswanger IA. Maternal Deaths From Suicide and Overdose in Colorado, 2004-2012. Obs tet Gynecol 2016; 128(6):1233-1240 Doi:10.1097/ aog.0000000000001695

3. Gavin AR, Lindhorst T and Lohr MJ. The prevalence and correlates of depressive symptoms among adolescent mothers: results from a 17-year longitudinal study. Women Health 201 1;51(6):525-545 Doi:10.1080/ 03630242.2011 .606355

4. Fuhr DC, Calvert C, Ronsmans C, Chandra PS, Sikander S, De Silva MJ and Patel V. Contribution of suicide and injuries to pregnancy-related mortality in low-income and middle-income countries: a systematic review and meta-analysis. Lancet Psychiatry 2014;1(3):213-225 Doi: 10.1016/s2215-0366(14)70282-2

5. World Health Organization. International Statistical Classification of Diseases and Related Health Problems 10th Revision (ICD-10) [Internet]. 2019 [updated 16 Sep; cited 202116 Sep]. Available from: https://icd. who.int/browse10/2019/en.

6. Hasegawa J, Katsuragi S, Tanaka H, Kubo T, Sekizawa A, Ishiwata I and Ikeda T. How should maternal death due to suicide be classified? Discrepancy between ICD-10 and ICD-MM. Bjog 2020; 127(6):665-667 Doi: $10.1111 / 1471-0528.16087$

7. Lommerse K, Knight M, Nair M, Deneux-Tharaux $C$ and van den Akker $T$. The impact of reclassifying suicides in pregnancy and in the postnatal period on maternal mortality ratios. Bjog 2019;126(9):1088-1092 Doi: $10.1111 / 1471-0528.15215$

8. Palladino $\mathrm{CL}$, Singh V, Campbell J, Flynn H and Gold $\mathrm{KJ}$. Homicide and suicide during the perinatal period: findings from the National Violent Death Reporting System. Obstet Gynecol 2011;118(5):1056-1063 Doi:10.1097/AOG.0b013e31823294da

9. Jago CA, Crawford SG, Gill SJ and Gagnon L. Mental Health and Maternal Mortality-When New Life Doesn't Bring Joy. J Obstet Gynaecol Can 2021;43(1):67-73. e61 Doi:10.1016/i.jogc.2020.06.016

10. Esscher A, Essén B, Innala E, Papadopoulos FC, Skalkidou A, Sundström-Poromaa I and Högberg U. Suicides during pregnancy and 1 year postpartum in Sweden, 1980-2007. Br J Psychiatry 2016;208(5):462-469 Doi:10.1192/bjp.bp. 114.161711 
11. Lega I, Maraschini A, D'Aloja P, Andreozzi S, Spettoli $D$, Giangreco $M$, . . . Donati S. Maternal suicide in Italy. Arch Womens Ment Health 2020;23(2):199-206 Doi: 10.1007/s00737-019-00977-1

12. Shea BJ, Reeves BC, Wells G, Thuku M, Hamel C, Moran J, ... Henry DA. AMSTAR 2: a critical appraisal tool for systematic reviews that include randomised or non-randomised studies of healthcare interventions, or both. BMJ 2017;358(j4008 Doi: 10.1 136/bmj.j4008

13. The Critical Appraisals Skills Programme. CASP checklist for qualitative research [Internet]. 2018 [updated 20 March]. Available from: https://casp-uk.net/casp-tools-checklists.

14. Johanna Briggs Institute. Critical Appraisal Tools [Internet]. 2018 [cited 202116 November]. Available from: http:// joannabriggs-webdev.org/research/critical-appraisal-tools.html

15. Guyatt G, Oxman AD, Akl EA, Kunz R, Vist G, Brozek J, . . . Schünemann HJ. GRADE guidelines: 1. Introduction-GRADE evidence profiles and summary of findings tables. J Clin Epidemiol 201 1;64(4):383-394 Doi: 10.1016/i.jclinepi.2010.04.026

16. Qin P, Agerbo E and Mortensen PB. Suicide risk in relation to socioeconomic, demographic, psychiatric, and familial factors: a national register-based study of all suicides in Denmark, 1981-1997. Am J Psychiatry 2003; 160(4):765-772 Doi:10.1176/appi. aip. 160.4.765

17. Mendez-Bustos P, Lopez-Castroman J, Baca-García E and Ceverino $A$. Life cycle and suicidal behavior among women. ScientificWorldJournal 2013;2013:485851 Doi: 10.1155/2013/485851

18. Jones I, Chandra PS, Dazzan P and Howard LM. Bipolar disorder, affective psychosis, and schizophrenia in pregnancy and the post-partum period. Lancet 2014;384(9956): 1789-1799 Doi:10.1016/s0140. 6736(14)61278-2

19. Austin MP, Kildea S and Sullivan E. Maternal mortality and psychiatric morbidity in the perinatal period: challenges and opportunities for prevention in the Australian setting. Med J Aust 2007; 186(7):364-367 Doi: 10.5694/j. 1326-5377.2007.tb00940.x

20. Castro e Couto T, Brancaglion MY, Cardoso MN, Faria GC, Garcia FD, Nicolato R, ... Corrêa H. Suicidality among pregnant women in Brazil: prevalence and risk factors. Arch Womens Ment Health 2016;19(2):343348 Doi:10.1007/s00737-015-0552-x

21. Lysell $H$, Dahlin $M$, Viktorin A, Ljungberg $E$, D'Onofrio BM, Dickman P and Runeson B. Maternal suicide - Register based study of all suicides occurring after delivery in Sweden 1974-2009. PloS One 2018;13(1):e0190133 Doi:10.1371/journal.pone.0190133

22. Galea LAM and Frokjaer VG. Perinatal Depression: Embracing Variability toward Better Treatment and Outcomes. Neuron 2019;102(1):13-16 Doi:10.1016/i. neuron.2019.02.023
23. Orsolini L, Valchera A, Vecchiotti R, Tomasetti C, lasevoli F, Fornaro $M, \ldots$ Bellantuono $C$. Suicide during Perinatal Period: Epidemiology, Risk Factors, and Clinical Correlates. Front Psychiatry 2016;7:138 Doi:10.3389/ fpsyt.2016.00138

24. Bachmann S. Epidemiology of Suicide and the Psychiatric Perspective. Int J Environ Res Public Health 2018;15(7):Doi:10.3390/ijerph15071425

25. Gentile S. Suicidal mothers. J Inj Violence Res 201 1;3(2):90-97 Doi:10.5249/jivr.v3i2.98

26. Singal $D$, Brownell $M$, Chateau D, Wall-Wieler E, Longstaffe S, Hanlon-Dearman A and Roos LL. Suicide and suicide attempts among women in the Manitoba Mothers and Fetal Alcohol Spectrum Disorder cohort: a retrospective matched analysis using linked administrative data. CMAJ Open 2017;5(3):E646-e652 Doi: 10.9778/cmajo.20160127

27. Crandall $M$, Sridharan $L$ and Schermer $C$. Depression and thoughts of death among disadvantaged mothers: risk factors and impact on maternal and child health. Arch Suicide Res 2010; 14(3):248-260 Doi:10.1080/ 13811118.2010 .494143

28. Agampodi S, Wickramage K, Agampodi T, Thennakoon U, Jayathilaka N, Karunarathna D and Alagiyawanna S. Maternal mortality revisited: the application of the new ICD-MM classification system in reference to maternal deaths in Sri Lanka. Reprod Health 2014; $11(1): 17$ Doi: 10.1186/1742-4755-11-17

29. Fisher J, Cabral de Mello M, Patel V, Rahman A, Tran T, Holton $S$ and Holmes W. Prevalence and determinants of common perinatal mental disorders in women in lowand lower-middle-income countries: a systematic review. Bull World Health Organ 2012;90(2):139g-149g Doi: 10.2471/blt. 11.091850

30. Chen YH and Lau G. Maternal deaths from suicide in Singapore. Singapore Med J 2008;49(9):694-697

31. Gausia K, Fisher C, Ali M and Oosthuizen J. Antenatal depression and suicidal ideation among rural Bangladeshi women: a community-based study. Arch Womens Ment Health 2009; 12(5):351-358 Doi: 10.1007/ s00737-009-0080-7

32. Huang H, Faisal-Cury A, Chan YF, Tabb K, Katon W and Menezes PR. Suicidal ideation during pregnancy: prevalence and associated factors among low-income women in São Paulo, Brazil. Arch Womens Ment Health 2012;15(2):135-138 Doi:10.1007/s00737012-0263-5

33. Shi $P$, Ren $H$, Li $H$ and Dai $Q$. Maternal depression and suicide at immediate prenatal and early postpartum periods and psychosocial risk factors. Psychiatry Res 2018;261:298-306 Doi:10.1016/i.psychres.2017.12.085

34. Gelaye B, Kajeepeta S and Williams MA. Suicidal ideation in pregnancy: an epidemiologic review. Arch Womens Ment Health 2016;19(5):741-751 Doi:10.1007/ s00737-016-0646-0 
35. Alhusen JL, Frohman N and Purcell G. Intimate partner violence and suicidal ideation in pregnant women. Arch Womens Ment Health 2015; 18(4):573-578 Doi: 10.1007/s00737-015-0515-2

36. Supraja TA, Thennarasu K, Satyanarayana VA, Seena TK, Desai G, Jangam KV and Chandra PS. Suicidality in early pregnancy among antepartum mothers in urban India. Arch Womens Ment Health 2016;19(6): 1101 1108 Doi:10.1007/s00737-016-0660-2

37. Bowen A, Stewart N, Baetz M and Muhajarine N. Antenatal depression in socially high-risk women in $\mathrm{Ca}$ nada. J Epidemiol Community Health 2009;63(5):414416 Doi:10.1136/jech.2008.078832

38. Collins $\mathrm{CH}$, Zimmerman $\mathrm{C}$ and Howard LM. Refugee, asylum seeker, immigrant women and postnatal depression: rates and risk factors. Arch Womens Ment Health 2011;14(1):3-1 1 Doi:10.1007/s00737-010-0198-7

39. Pearson RM, Evans J, Kounali D, Lewis G, Heron J, Ramchandani PG, . . . Stein A. Maternal depression during pregnancy and the postnatal period: risks and possible mechanisms for offspring depression at age 18 years. JAMA Psychiatry 2013;70(12):1312-1319 Doi: 10.1001/jamapsychiatry.2013.2163

40. Alves MM, Alves SV, Antunes MB and Santos DL. External causes and maternal mortality: proposal for classification. Rev Saude Publica 2013;47(2):283-291 Doi: 10.1590/s0034-8910.2013047003642

41. Reardon DC and Thorp JM. Pregnancy associated death in record linkage studies relative to delivery, termination of pregnancy, and natural losses: A systematic review with a narrative synthesis and meta-analysis. SAGE Open Med 2017;5:2050312117740490 Doi:10.1177/2050312117740490

42. Tabb KM, Gavin AR, Guo Y, Huang H, Debiec K and Katon W. Views and experiences of suicidal ideation during pregnancy and the postpartum: findings from interviews with maternal care clinic patients. Women Health 2013;53(5):519-535 Doi:10.1080/0363024 2.2013.8040244

43. Knasmüller P, Kotal A, König D, Vyssoki B, Kapusta $N$ and Blüml V. Maternal suicide during pregnancy and the first postpartum year in Austria: Findings from 2004 to 2017. Psychiatry Res 2019;281:112530 Doi:10.1016/i.psychres.2019.112530

44. Oates M. Perinatal psychiatric disorders: a leading cause of maternal morbidity and mortality. $\mathrm{Br}$ Med Bull 2003;67:219-229 Doi:10.1093/bmb/ldg01 1

45. Thornton C, Schmied V, Dennis CL, Barnett B and Dahlen HG. Maternal deaths in NSW (2000-2006) from nonmedical causes (suicide and trauma) in the first year following birth. Biomed Res Int 2013;2013:623743 Doi: 10. 1 155/2013/623743

46. Bronisch T and Lieb R. Maternal suicidality and suicide risk in offspring. Psychiatr Clin North Am 2008;31 (2):213221 Doi:10.1016/i.psc.2008.01.003

47. Kuramoto SJ, Stuart EA, Runeson B, Lichtenstein P, Langstrom $\mathrm{N}$ and Wilcox HC. Maternal or Paternal Suicide and Offspring's Psychiatric and Suicide-Attempt Hospitalization Risk. Pediatrics 2010;126(5):e1026-e 1032 Doi: 10.1542/peds.2010-0974

48. Stein A, Pearson RM, Goodman SH, Rapa E, Rahman A, McCallum M, . . . Pariante CM. Effects of perinatal mental disorders on the fetus and child. Lancet 2014;384(9956): 1800-1819 Doi:10.1016/s01406736(14)61277-0

49. Lieb R, Bronisch T, Höfler M, Schreier A and Wittchen $\mathrm{HU}$. Maternal suicidality and risk of suicidality in offspring: findings from a community study. Am J Psy chiatry 2005; 162(9):1665-1671 Doi:10.1176/appi. ajp. 162.9.1665 